\title{
Pengaruh pendekatan Problem Posing terhadap prestasi belajar matematika siswa berdasarkan gaya kognitif
}

\section{Muhammad Muzaini ${ }^{1}$}

\begin{abstract}
Abstrak: Penelitian eksperimen ini bertujuan untuk mengetahui: 1) perbedaan prestasi belajar matematika siswa antara siswa yang bergaya kognitif field independent diajar dengan pendekatan problem posing dan siswa diajar yang dengan pendekatan konvensional; 2) perbedaan prestasi belajar matematika siswa antara siswa bergaya kognitif field dependent yang diajar dengan pendekatan problem posing dan siswa yang diajar dengan pendekatan konvensional; dan 3) interaksi antara pendekatan pembelajaran dengan gaya kognitif terhadap prestasi belajar siswa. Instrumen penelitian yaitu lembar observasi aktivitas guru, lembar observasi aktivitas siswa, instrumen GEFT, dan angket respon siswa. Analisis data menggunakan statistik deskriptif dan inferensial dengan bantuan SPSS versi 16,0. Hasil penelitian menunjukkan bahwa prestasi belajar matematika siswa yang bergaya kognitif field independent yang diajar dengan pendekatan problem posing lebih baik dari prestasi belajar siswa yang diajar dengan pendekatan konvensional, ada perbedaan prestasi belajar matematika siswa yang mempunyai gaya kognitif field dependent yang diajar dengan pendekatan problem posing dan prestasi belajar matematika siswa yang diajar dengan pendekatan konvensional, dan tidak ada interaksi antara pendekatan problem posing dan gaya kognitif terhadap prestasi belajar matematika siswa.
\end{abstract}

Kata Kunci: Problem Posing; Gaya Kognitif; Field Independent; Field Dependent; Prestasi Belajar

\begin{abstract}
This experimental research aims to find out: 1) the difference of mathematics achievement of students who have fieldindependent cognitive style taught with problem posing and conventional approach; 2) the difference of mathematics achievement of students who have field-dependent cognitive style taught with problem posing and conventional approach; and 3) interaction between learning approach and cognitive style towards students' mathematics achievement. The instruments of this research are teacher's observation sheet, students' activity observation sheet, GEFT instrument, and the questionnaire of students' response. Research data is analyzed through descriptive
\end{abstract}

\footnotetext{
${ }^{1}$ Universitas Cokroaminoto, Palopo, Indonesia, ucha2610@gmail.com
} 
and inferential statistics using SPSS version 16,0. The research found that mathematics achievement of students who have fieldindependent taught with problem posing is better than those who taught with conventional approach, field-dependent students have different mathematics achievement that taught with problem posing and conventional approach, and there is no interaction between problem posing approach and cognitive style towards mathematics achievement of students.

Kata Kunci: Problem Posing; Cognitive Style; Field Independent; Field Dependent; Mathematics Achievement

\section{A. Pendahuluan}

Matematika sebagai ilmu dasar memegang peranan yang penting dalam pengembangan sains dan teknologi. Matematika merupakan salah satu mata pelajaran yang diajarkan pada setiap jenis dan jenjang pendidikan, baik pendidikan umum maupun pendidikan kejuruan, mulai dari pendidikan dasar sampai perguruan tinggi. Dengan mempelajari matematika, siswa diharapkan dapat berpikir secara logis, analitis, kritis, dan kreatif serta diharapkan mampu memecahkan segala masalah yang dihadapi, baik masalah yang berkaitan dengan pelajaran matematika, maupun yang berkaitan dengan kehidupan sehari-hari.

Hal ini sejalan dengan tujuan umum pembelajaran matematika pada jenjang pendidikan dasar dan menengah, yaitu: 1) memahami konsep matematika, menjelaskan keterkaitan antar konsep dan mengaplikasikan konsep atau algoritma secara luwes, akurat, efesien, dan tepat dalam pemecahan masalah, 2) menggunakan penalaran pada pola dan sifat, melakukan manipulasi matematika dalam membuat generalisasi, menyusun bukti, atau menjelaskan gagasan dan pernyataan matematika, 3) memecahkan masalah yang meliputi kemampuan memahami masalah, merancang model matematika, menyelesaikan model dan menafsirkan solusi yang diperoleh, 4) mengkomunikasikan gagasan dengan simbol, tabel, diagram, atau media lain untuk memperjelas keadaan atau masalah, 5) memiliki sikap menghargai kegunaan matematika dalam kehidupan, yaitu memiliki rasa ingin tahu, perhatian, dan minat dalam mempelajari matematika, serta sikap ulet dan percaya diri dalam pemecahan masalah (Soedjadi, 1991). 
Pembelajaran matematika di sekolah selama ini pada umumnya menggunakan urutan sajian sebagai berikut: diajarkan teori/ definisi/teorema, diberikan contoh-contoh, dan terakhir diberikan latihan atau soal (Soedjadi, 2001; Sembiring, Hadi, \& Dolk, 2008). Wahyu dan Mahfudy (2016) menambahkan karakteristik pembelajaran matematika yang banyak ditemukan di kelas yaitu fokus pada perhitungan (drill), peran guru lebih dominan (teacher-centered), siswa belum diberikan kesempatan dan didorong untuk menyampaikan pendapat (reasoning), tidak membangun pemahaman konsep, belum berorientasi pemecahan masalah (problem solving), dan tidak dikaitkan dengan kehidupan seharihari. Pembelajaran semacam ini biasa disebut dengan pembelajaran konvensional atau tradisional. Pola pembelajaran semacam itu menyebabkan guru memiliki otoritas penuh di kelas sementara siswa hanya menjadi pendengar dan pencatat yang baik (Wahyu, 2015).

Belajar merupakan suatu kegiatan kreatif. Belajar tidak berarti hanya menyerap tetapi juga membangun pengetahuan. Rasa ingin tahu (curiosity) merupakan sifat alamiah yang dimiliki manusia. Sifat ini sangat bermanfaat sebagai motivasi bagi seseorang untuk terus menambah pengetahuan yang dimilikinya. Agar siswa termotivasi untuk belajar secara mandiri, maka rasa ingin tahu siswa perlu dimunculkan dan dikembangkan.

Pada anak usia balita sifat ini terlihat sangat jelas, mereka selalu ingin meraih benda-benda di sekitarnya. Benda-benda itu diamati dengan cara dipandangi, diputar-putar, dimasukkan ke mulut, atau dilemparkan kemudian berusaha diraih kembali. Anak yang sudah dapat berbicara akan terus mengajukan pertanyaan kepada orang dewasa. Akan tetapi seringkali orang dewasa tidak mengacuhkan pertanyaan anak, bahkan menganggap anak lancang sehingga membuat anak takut bertanya. Hal ini juga terjadi di sekolah. Menurut Arikunto (1990), anak yang memiliki rasa ingin tahu yang besar biasanya dipandang "merepotkan" guru, karena selalu mengajukan pertanyaan yang menyebabkan waktu untuk melakukan sesuatu atau untuk melanjutkan pelajaran tersita dan guru merasa takut tidak mampu menjawab pertanyaan itu sehingga dapat menurunkan martabat guru tersebut. Akibatnya dalam mengikuti pembelajaran, anak sungkan atau malas bertanya, meskipun belum 
mengerti materi yang diberikan. Rasa ingin tahu siswa semakin menurun dan berdampak pada rendahnya motivasi belajar.

NCTM (National Council of Teachers of Mathematics, 2000) merekomendasikan agar dalam pembelajaran matematika, para siswa diberikan kesempatan untuk mengajukan soal sendiri. Selanjutnya menurut Moses, Bjork, dan Goldenberg (1993) ketika siswa diminta menjawab pertanyaan atau soal yang diajukan oleh guru, akan ditemukan tingkat kecemasan yang tinggi dalam diri siswa. Ini disebabkan siswa merasa takut salah atau menganggap idenya tidak cukup bagus. Dalam pembelajaran yang menerapkan problem posing, siswa dituntun untuk mengajukan masalah atau pertanyaan yang sesuai dengan minat mereka dan memikirkan cara penyelesaiannya, sehingga perasaan tersebut dapat direduksi. Selain itu, menurut Hamzah (2002) perhatian dan komunikasi matematika siswa yang diajar menggunakan pendekatan problem posing akan lebih baik dibandingkan dengan siswa yang diajar dengan menggunakan pembelajaran biasa.

Beberapa penelitian menunjukan bahwa pembelajaran dengan problem posing dapat meningkatkan kemampuan siswa. Hasil penelitian oleh Syam (2008) mengungkapkan bahwa dengan pendekatan problem posing dapat meningkatkan prestasi belajar matematika siswa. Secara kuantitatif peningkatan yang dicapai yaitu: 1) aktivitas siswa meningkat $60 \%$, 2) motivasi belajar siswa mencapai $65 \%, 3)$ proses pembelajaran berjalan secara dinamis meningkat $70 \%$, dan 4) peran guru dalam pembelajaran meningkat $15 \%$ dari keseluruhan proses pembelajaran, yang berarti meningkat 60\%. Zulkifli (2003) menerapkan problem posing pada materi Phytagoras di siswa kelas 2 SLTPN 22 Surabaya memberikan hasil yang positif.

Selain beberapa hasil penelitian dia atas, Siswono (1999) juga memaparkan beberapa tanggapan yang diungkapkan para ahli:

1. Dengan membuat soal dan mengerjakannya, menyebabkan materi pelajaran mudah diingat (English, 1977; Suryanto, 1998);

2. Membuat soal dan mengerjakan membantu siswa memecahkan masalah atau menyelesaikan soal lain (English, 1977);

3. Tugas membuat soal membantu siswa memahami suatu konsep (English, 1997); 
4. Tugas membuat soal mendorong siswa lebih banyak membaca materi pelajaran (English, 1997; Silver \& Cai, 1996).

Belajar matematika akan optimal jika siswa terlibat secara aktif dalam membuat, bukan hanya strategi penyelesaian, tetapi juga masalah yang membutuhkan strategi tersebut (Moses, Bjork, \& Goldenberg, 1993). NCTM (2000) menganjurkan memberi kesempatan kepada siswa untuk menyelidiki dan membuat pertanyaan berdasarkan suatu situasi. Lebih lanjut, NCTM menegaskan bahwa siswa harus memiliki pengalaman mengenali dan merumuskan masalah mereka sendiri, sehingga kegiatan tersebut merupakan inti dari melakukan matematika. Dalam Professional Standards for Teaching Mathematics (NCTM, 1991) disarankan agar siswa harus diberi kesempatan untuk merumuskan masalah dari situasi yang diberikan dan menciptakan masalah baru dengan memodifikasi kondisi dari soal yang diberikan.

Menurut Upu (2003), problem posing dapat dilakukan secara individual atau klasikal (classical), berpasangan (in pairs), atau secara berkelompok (groups). Masalah atau soal yang diajukan oleh siswa secara individual tidak memuat intervensi siswa lain. Soal diajukan tanpa terlebih dahulu ditanggapi oleh siswa lain. Hal ini dapat mengakibatkan soal kurang berkembang atau kandungan informasinya kurang lengkap. Soal yang diajukan secara berpasangan dapat lebih berbobot dibandingkan dengan soal yang diajukan secara individual, dengan syarat terjadi kolaborasi di antara kedua siswa yang berpasangan tersebut. Jika soal dirumuskan oleh sebuah kelompok kecil (tim), maka kualitasnya akan lebih tinggi baik dari aspek tingkat keterselesaian maupun kandungan informasinya. Kerjasama di antara siswa dapat memacu kreativitas serta saling melengkapi kekurangan mereka.

Dalam pembelajaran matematika, hal lain yang perlu diperhatikan oleh guru adalah gaya kognitif siswa. Hal ini disebabkan karena kemampuan seseorang dalam memproses infomasi berbeda-beda. Guru harus memahami bahwa karakteristik yang dimiliki oleh siswa beragam. Tidak ada siswa yang memiliki daya tangkap, daya serap, daya pikir dan daya kecerdasan yang sama antara siswa yang satu dengan siswa yang lainnya dalam sebuah kelas atau sekolah. Dengan mengetahui adanya perbedaan individual dalam gaya kognitif, guru dapat memahami bahwa 
siswa yang hadir di kelas memiliki cara yang berbeda-beda dalam mendekati masalah atau menghadapi tugas-tugas yang diberikan.

Menurut Slameto (2003), perbedaan antar pribadi menyangkut sikap, pilihan atau strategi secara stabil yang menentukan cara-cara khas seseorang dalam menerima, mengingat, berpikir, dan memecahkan masalah disebut dengan cognitive styles atau gaya kognitif yang terdiri dari Field Independent (FI) dan Field Dependent (FD). Dalam sumber yang sama dinyatakan bahwa Individu yang belajar dengan gaya field independent cenderung menyatakan suatu gambaran lepas dari latar belakang gambaran tersebut, serta mampu membedakan objek-objek dari konteks sekitarnya dengan lebih mudah, memandang keadaan sekeliling lebih secara analitis dan umumnya mampu dengan mudah menghadapi tugas-tugas yang memerlukan perbedaan-perbedaan dan analisis. Umumnya siswa yang field independent kurang dipengaruhi oleh lingkungan, atau bahkan tidak dipengaruhi lingkungan.

Slameto (2003) lebih lanjut menjelaskan bahwa gaya kognitif field dependent kebalikan dari gaya kognitif field independent. Individu dengan gaya kognitif ini menerima sesuatu secara global dan mengalami kesulitan dalam memisahkan diri dari keadaan sekitar, cenderung mengenal dirinya sebagai bagian dari suatu kelompok. Dalam interaksi sosial mereka cenderung untuk lebih perspektif dan peka. Umumnya siswa dengan gaya kognitif seperti ini sangat dipengaruhi oleh lingkungan atau bergantung pada lingkungan.

Gaya kognitif berkaitan erat dengan pribadi seseorang, yang tentunya dipengaruhi oleh pendidikan dan riwayat perkembangannya. Gaya kognitif dapat dipandang sebagai suatu variabel dalam pembelajaran. Dalam hal ini kedudukannya merupakan variabel karakteristik siswa, dan keberadaannya bersifat internal. Artinya gaya kognitif merupakan kapabilitas seseorang yang berkembang seiring dengan perkembagan kecerdasaannya. Witkin (1977) menilai gaya kognitif mempunyai potensi yang besar bilamana dimanfaatkan dalam upaya peningkatan efektivitas proses belajar mengaja. Gaya kognitif juga ditentukan oleh lingkungan yang dirancang guru, karena itu guru perlu memperhatikan gaya kognitif yang dimiliki oleh seorang siswa dengan cara menerapkan berbagai macam strategi, pendekatan, model dalam pembelajaran yang mampu mengakomodir kedua jenis gaya kognitif tersebut. Dengan adanya 
interaksi antara gaya kognitif dengan pendekatan pembelajaran, kemungkinan prestasi belajar siswa dapat dicapai dengan optimal. Siswa yang memiliki gaya kognitif tertentu memerlukan strategi pembelajaran tertentu untuk memperoleh prestasi belajar yang baik.

Berdasarkan uraian di atas, ada dua faktor utama yang dapat mendukung kemampuan pengajuan masalah matematika (problem posing) yaitu faktor internal dan eksternal. Faktor internal terdiri dari kemampuan prasyarat, kemampuan berpikir konvergen, kemampuan berpikir divergen, kreativitas, persepsi dan gaya kognitif. Sedangkan faktor eksternal meliputi pendekatan, metode, atau strategi yang digunakan oleh guru dalam proses pembelajaran. Mengingat keterbatasan penulis, maka dalam penelitian ini dipilih faktor internal berupa gaya kognitif. Dengan asumsi faktor internal tersebut berpengaruh terhadap kemampuan pengajuan masalah matematika (problem posing).

Penelitian ini bertujuan untuk mengetahui: 1) perbedaan prestasi belajar matematika siswa antara siswa yang bergaya kognitif field independent diajar dengan pendekatan problem posing dengan siswa lainnya yang diajar dengan pendekatan konvensional, 2) perbedaan prestasi belajar matematika siswa antara siswa yang bergaya kognitif field dependent diajar dengan pendekatan problem posing dengan siswa lainnya yang diajar dengan pendekatan konvensional, 3) interaksi antara pendekatan pembelajaran dengan gaya kognitif field independent dan field dependent terhadap prestasi belajar siswa.

\section{B. METODE PENELITIAN}

Penelitian ini merupakan penelitian eksperimen semu dimana peneliti memanipulasi variabel dengan memberikan perlakuan dengan membandingkan 2 kelas. Selanjutnya kedua kelas dievaluasi untuk melihat perubahan atau peningkatan yang terjadi terhadap hasil belajar matematika setelah mendapat perlakuan pembelajaran dengan pendekatan problem posing dengan yang mendapat perlakuan pembelajaran dengan pendekatan konvensional dengan memperhitungkan gaya kognitif.

Mengingat keterbatasan waktu dan dana maka populasi dalam penelitian ini adalah seluruh SMP Swasta yang terakreditasi B di kota Makassar tahun pelajaran 2011/2012 (studi pada siswa kelas VII). Metode 
pengambilan sampel yang digunakan dalam penelitian ini menggunakan metode Random Cluster Sampling. Memilih secara random dua sekolah swasta dari seluruh sekolah swasta yang telah terakreditasi B di Kota Makassar. Dalam penelitian ini terpilih sekolah SMP Nasional dan MTs Muallimin Muhammadiyah Makassar karena kedua sekolah tersebut terakreditasi B berdasarkan data dari Dinas Pendidikan Kota Makassar. Selain itu, tenaga pengajar pada kedua sekolah memiliki kualifikasi jenjang yang sama yaitu tamatan program S1 pendidikan matematika. Kedua sekolah juga melaksanakan kegiatan pembelajarannya yang mengacu pada Kurikulum Tingkat Satuan Pendidikan (KTSP).

Menentukan secara cluster masing-masing satu kelas dari 6 kelas VII di SMP Nasional dan satu kelas dari 3 kelas VII di MTs Muallimin Muhammadiyah Makassar. Berdasarkan hasil analisis varians untuk 9 kelas VII tersebut diperoleh bahwa kesembilan kelas tersebut memiliki nilai rata-rata yang sama. Dari hasil komputasi secara statistik untuk uji homogenitas, diperoleh nilai $\mathrm{F}=0,169$ dan nilai $\mathrm{p}$-value $=0,762$, dengan mengambil nilai $\alpha=5 \%$ maka nilai $p$-value $>\alpha=0,05$. Karena nilai $p$-value lebih besar dari nilai a maka HO diterima yang menyatakan bahwa kesembilan kelas itu memiliki nilai rata-rata yang hampir sama secara statistik atau homogen dalam hal prestasi belajar matematikanya.

Menentukan secara random kedua kelas yang akan dipilih yaitu masing-masing 1 kelas dari satu SMP untuk menentukan kelas kontrol dan kelas experimen. Pada penelitian ini yang terpilih menjadi kelas experimen adalah kelas VIIC MTs Muallimin Muhammadiyah Makassar dan yang menjadi kelas kontrol adalah kelas VIIE SMP Nasional Makassar. Siswa yang terlibat dari kedua kelas tersebut merupakan sampel yang akan diselidiki dalam penelitian ini.

Dari hasil tes GEFT (Group Embedded Figures Test) dapat dilihat bahwa dari kelas kontrol terdapat 17 siswa yang memiliki gaya kognitif field independent dan 19 siswa memiliki gaya kognitif field dependent. Untuk kelas eksperimen terdapat 20 siswa yang memiliki gaya kognitif field independent dan 14 siswa yang memiliki gaya kognitif field dependent.

Desain pada penelitian ini adalah post-test control group yang merupakan bentuk dari True Experimental Design. Dalam desain ini, terdapat dua kelompok yang dipilih secara cluster random sampling. 
Kelompok pertama disebut kelompok eksperimen, yang akan diberikan perlakuan berupa pengajaran dengan menggunakan pendekatan problem posing. Kelompok yang kedua disebut kelompok kontrol, yang akan diberikan perlakuan berupa pengajaran dengan pembelajaran konvensional.

Desain penelitian eksperimen dalam penelitian ini dapat digambarkan dengan bagan rancangan seperti pada tabel berikut.

Tabel 1. Model Desain Penelitian

\begin{tabular}{|c|c|c|}
\hline $\begin{array}{l}\mathrm{R} \\
\mathrm{R}\end{array}$ & $\begin{array}{ll}X & \mathrm{O}_{1} \\
\mathrm{O}_{2}\end{array}$ & $\begin{array}{l}\mathrm{O}_{1}: \text { Hasil Posttest Kolompok Kontrol } \\
\mathrm{O}_{2} \text { : Hasil Posttest kelompok Eksperimen } \\
\text { Pengaruh perlakuan }\left(\mathrm{O}_{1}: \mathrm{O}_{2}\right)\end{array}$ \\
\hline
\end{tabular}

Dalam penelitian ini terdiri dari dua variabel, yaitu variabel bebas dan variabel terikat. Variabel bebas yaitu pembelajaran dengan menggunakan pendekatan problem posing sedangkan variabel terikatnya adalah hasil belajar. Gambaran pelaksanaan penelitian ini terlihat pada tabel 2 dibawah ini:

Tabel 2. Matriks Variabel Penelitian

\begin{tabular}{|c|c|c|c|}
\cline { 3 - 4 } \multicolumn{2}{c|}{} & \multicolumn{2}{c|}{ Pendekatan Mengajar } \\
\hline & & Problem Possing & Konvensional \\
\cline { 3 - 4 } & $\mathrm{FI}$ & $\mathrm{PP}-\mathrm{Fl}$ & $\mathrm{PK}-\mathrm{FI}$ \\
\hline & $\begin{array}{c}\text { FIELD } \\
\text { DEPENDENT }\end{array}$ & PP-field dependent & PK-field dependent \\
\hline
\end{tabular}

Keterangan:

$\mathrm{PP}-\mathrm{Fl} \quad$ : Problem posing dengan gaya kognitif field independent

PP-FD : Problem posing dengan gaya kognitif field dependent

PK-FI : Pendekatan konvensional dengan gaya kognitif field independent

PK-FD : Pendekatan konvensional dengan gaya kognitif field dependent

GK : Gaya Kognitif

Untuk mengumpulkan data dalam rangka eksperimen, digunakan instrumen penelitian berupa lembar observasi (pengamatan), angket respon siswa, dan tes hasil belajar. Sedangkan untuk tes hasil belajar, digunakan Tes Hasil Belajar (THB). 
Data dalam penelitian ini akan dikumpulkan dengan cara sebagai berikut:

1. Observasi (pengamatan): Lembar observasi diberikan kepada seorang pengamat untuk diisi dengan cara menuliskan cek list $(\sqrt{ })$ sesuai dengan keadaan yang diamati.

2. Tes: Data prestasi belajar siswa dikumpulkan melalui pemberian tes. Tes akan diberikan setelah proses pembelajaran (tes akhir).

Adapun instrumen pendukung dalam penelitian ini meliputi: Tes GEFT (Group Embedded Figures Test). GEFT adalah alat ukur yang dikembangkan untuk menggolongkan seseorang apakah termasuk gaya kognitif field independent atau field dependent. Data yang dikumpulkan dari penelitian ini akan diolah dengan menggunakan analisis statistik yaitu analisis statistik deskriptif dan analisis statistik inferensial. Dalam penelitian ini, analisis statistik dekriptif digunakan untuk mendeskripsikan hasil belajar matematika siswa pada setiap kelompok yang telah dipilih. Termasuk dalam statistik deskriptif antara lain penyajian data melalui tabel, grafik, mean, median, modus, standar deviasi, dan perhitungan persentase (Sugiyono, 2008). Jenis data berupa hasil belajar siswa selanjutnya dikategorikan secara kuantitatif berdasarkan teknik kategorisasi yang ditetapkan oleh Departemen Pendidikan Nasional (1999) adalah sebagai berikut:

Tabel 3. Interprestasi Kategori Nilai Hasil Belajar

\begin{tabular}{|c|l|}
\hline Nilai Hasil Belajar & \multicolumn{1}{|c|}{ Kategori } \\
\hline $90-100$ & Sangat Tinggi \\
\hline $80-89$ & Tinggi \\
\hline $65-79$ & Sedang \\
\hline $55-64$ & Rendah \\
\hline$<55$ & Sangat Rendah \\
\hline
\end{tabular}

Untuk menguji hipotesis penelitian dilakukan terlebih dahulu uji asumsi yaitu uji homogenitas.

1. Uji Homogenitas

Uji homogenitas dilakukan untuk menyelidiki variansi kedua sampel sama atau tidak. Uji yang digunakan adalah uji Levene's Test. Jika sampel tersebut memiliki varians yang sama, maka keduanya 
dikatakan homogen. Pada uji Levene's Test digunakan taraf signifikansi $5 \%$ atau 0,05 . Kriteria pengujian hipotesis adalah jika nilai probabilitas ( $p$-value) lebih besar dari taraf signifikansi $\alpha=0,05$, maka secara statistik kedua varian sama atau data homogen.

2. Menguji Hipotesis dengan uji T dan Anova Dua jalur.

Dalam penelitian ini menggunakan uji-T dan analisis variansi dua jalur dengan sel tidak sama. Analisis varian dua jalur digunakan untuk melihat interaksi gaya kognitif dan pendekatan problem posing terhadap prestasi belajar matematika siswa.

\section{Hasil Penelitian dan Pembahasan}

Data siswa yang tergolong gaya kognitif field independent dan gaya kognitif field dependent diperoleh dari tes GEFT yang diberikan pada pertemuan awal, selanjutnya dikelompokkan dalam 2 kategori.

Skor $\geq 9 \quad:$ Gaya kognitif field Independent

Skor $<9$ : Gaya kognitif field dependent

Ringkasan analisisnya adalah sebagai berikut:

Tabel 4. Hasil Kategori Gaya Kognitif Siswa

\begin{tabular}{|c|c|c|}
\hline Kategori Gaya Kognitif & Eksperimen & Kontrol \\
\hline Field independent & 20 & 17 \\
\hline Field dependent & 14 & 19 \\
\hline
\end{tabular}

\section{Analisis Deskriptif}

Perbandingan data prestasi belajar siswa gaya kognitif field independent dan siswa gaya kognitif field dependent pada kelas eksperimen dan kontrol disajikan pada tabel 5 di bawah ini.

Tabel 5. Perbandingan Data Prestasi Belajar Siswa

\begin{tabular}{|ll|r|r|r|}
\hline Kelas & Gaya Kognitif & Mean & Std. Deviation & $\mathrm{N}$ \\
\hline Eksperimen & Kognitif FI & 80,6500 & 7,32174 & 20 \\
& Kognitif FD & 67,6429 & 5,55542 & 14 \\
& Total & 75,2941 & 9,23278 & 34 \\
\hline Kontrol & Kognitif FI & 65,0588 & 12,12163 & 17 \\
& Kognitif FD & 57,8421 & 12,41533 & 19 \\
& Total & 61,2500 & 12,64092 & 36 \\
\hline Total & Kognitif FI & 73,4865 & 12,47580 & 37 \\
& Kognitif FD & 62,0000 & 11,11024 & 33 \\
& Total & 68,0714 & 13,10749 & 70 \\
\hline
\end{tabular}




\section{Analisis Inferensial}

Hasil analisis statistika inferensial dimaksudkan untuk menjawab hipotesis penelitian yang telah dirumuskan sekaligus menjawab pertanyaan penelitian. Sebelum melakukan analisis statistika inferensial terlebih dahulu dilakukan uji asumsi yaitu uji homogenitas dan dilanjutkan ke uji hipotesis.

a) Uji Homogenitas (Pertanyaan Penelitian Pertama)

Uji homogenitas digunakan untuk mengetahui beberapa varian data adalah sama atau tidak. Uji yang digunakan adalah uji kesamaan varian (homogenitas) dengan Levene's Test. Dengan program Statistical Package for Social Sciense (SPSS) versi 16,0. Adapun hasil analisinya diuraikan pada tabel 6 berikut.

Tabel 6. Uji Homogenitas Pertanyaan Penelitian Pertama

Independent Samples Test

\begin{tabular}{|c|c|c|c|c|c|c|c|c|c|c|}
\hline & \multicolumn{2}{|c|}{$\begin{array}{l}\text { Levene's Test for } \\
\text { Equality of Variances }\end{array}$} & \multicolumn{7}{|c|}{ t-test for Equality of Means } \\
\hline & & \multirow[b]{2}{*}{$\mathrm{F}$} & \multirow[b]{2}{*}{ Sig. } & \multirow[b]{2}{*}{$t$} & \multirow[b]{2}{*}{$d f$} & \multirow[b]{2}{*}{ Sig. (2-tailed) } & \multirow{2}{*}{$\begin{array}{c}\text { Mean } \\
\text { Difference }\end{array}$} & \multirow{2}{*}{$\begin{array}{l}\text { Std. Error } \\
\text { Difference }\end{array}$} & \multicolumn{2}{|c|}{$\begin{array}{c}95 \% \text { Confidence } \\
\text { Interval of the } \\
\text { Difference }\end{array}$} \\
\hline & & & & & & & & & Lower & Upper \\
\hline & $\begin{array}{l}\text { Equal variances } \\
\text { assumed }\end{array}$ & 5.766 & .022 & 4.817 & 35 & .000 & 15.59118 & 3.23675 & 9.02022 & 22.16213 \\
\hline & $\begin{array}{l}\text { Equal variances } \\
\text { not assumed }\end{array}$ & & & 4.633 & 25.405 & .000 & 15.59118 & 3.36505 & 8.66632 & 22.51603 \\
\hline
\end{tabular}

Pada Kolom Levene's Test for equality of variances nilai $\mathrm{F}=5.766$ dan $p$-value $=0.022$, dengan mengambil nilai $\alpha=0,05$, maka nilai $p$-value $<\alpha=0,05$ sehingga $H_{0}$ ditolak dan $H_{1}$ diterima, dimana $H_{1}$ menyatakan bahwa kedua variabel tersebut tidak homogen.

b) Uji Hipotesis (Pertanyaan Penelitian pertama)

Pengujian hipotesis dalam penelitian ini menggunakan uji T karena variabel tersebut tidak homogen maka yang kita perhatikan baris yang ada di bawah pada kolom $t$-test for Equality of Means nilai $\mathrm{t}=$ 4.633 dan $p$-value $=0.0001$, dengan mengambil $\alpha=0,05$, maka nilai $p$ value $<\alpha=0,05$ sehingga $H_{0}$ ditolak dan $H_{1}$ diterima, yang menyatakan prestasi belajar matematika siswa antara siswa yang bergaya kognitif $\mathrm{FI}$ yang diajar dengan pendekatan problem posing lebih baik dari prestasi belajar siswa bergaya kognitif FI yang diajar dengan pendekatan konvensional. 
c) Uji Homogenitas (Pertanyaan Penelitian Kedua)

Uji homogenitas digunakan untuk mengetahui beberapa varian data adalah sama atau tidak. Uji yang digunakan adalah uji kesamaan varian (homogenitas) dengan Levene's Test. Dengan program Statistical Package for Social Sciense (SPSS) versi 16,0. Adapun hasil analisinya diuraikan pada tabel 7 .

Tabel 7. Uji Homogenitas Pertanyaan Penelitian Kedua

\begin{tabular}{|c|c|c|c|c|c|c|c|c|c|c|}
\hline \multicolumn{11}{|c|}{ Independent Samples Test } \\
\hline & & \multicolumn{2}{|c|}{$\begin{array}{l}\text { Levene's Test for } \\
\text { Equality of Variances }\end{array}$} & \multicolumn{7}{|c|}{ t-test for Equality of Means } \\
\hline & & \multirow[b]{2}{*}{$\mathrm{F}$} & \multirow[b]{2}{*}{ Sig. } & \multirow[b]{2}{*}{$t$} & \multirow[b]{2}{*}{$d f$} & \multirow[b]{2}{*}{ Sig. (2-tailed) } & \multirow{2}{*}{$\begin{array}{c}\text { Mean } \\
\text { Difference }\end{array}$} & \multirow{2}{*}{$\begin{array}{l}\text { Std. Error } \\
\text { Difference }\end{array}$} & \multicolumn{2}{|c|}{$\begin{array}{c}95 \% \text { Confidence } \\
\text { Interval of the } \\
\text { Difference }\end{array}$} \\
\hline & & & & & & & & & Lower & Upper \\
\hline Nilai & $\begin{array}{l}\text { Equal variances } \\
\text { assumed }\end{array}$ & 11.841 & .002 & 2.749 & 31 & .010 & 9.80075 & 3.56499 & 2.52992 & 17.07159 \\
\hline & $\begin{array}{l}\text { Equal variances } \\
\text { not assumed }\end{array}$ & & & 3.051 & 26.411 & .005 & 9.80075 & 3.21203 & 3.20333 & 16.39817 \\
\hline
\end{tabular}

Pada Kolom Levene's Test for equality of variances nilai $\mathrm{F}=11.841$ dan $p$-value $=0.002$, dengan mengambil nilai $\alpha=0,05$, maka nilai $p$ value $<\alpha=0,05$, sehingga $H_{0}$ ditolak dan $H_{1}$ diterima, dimana $H_{1}$ menyatakan bahwa kedua variabel tersebut tidak homogen.

d) Uji hipotesis (Pertanyaan Penelitian Kedua)

Pengujian hipotesis dalam penelitian ini menggunakan uji T. Karena Variabel tersebut tidak homogen maka yang kita perhatikan baris yang ada dibawah Pada Kolom $t$-test for Equality of Means nilai $\mathrm{t}=$ 3.051 dan $p$-value $=0.005$, dengan mengambil nilai $\alpha=0,05$, maka nilai $p$-value $<\alpha=0,05$ sehingga $\mathrm{H}_{0}$ ditolak dan $\mathrm{H}_{1}$ diterima, yang menyatakan ada perbedaan prestasi belajar matematika siswa antara siswa yang bergaya kognitif FD yang diajar dengan pendekatan problem posing dan siswa yang bergaya kognitif FD yang diajar dengan pendekatan konvensional

e) Uji Hipotesis (Pertanyaan Penelitian Ketiga)

Berdasarkan dari hasil perhitungan anova dua jalur untuk melihat interaksi antara gaya kognitif dan pendekatan problem posing terhadap prestasi belajar diperoleh tabel 8 sebagai berikut. 
Tabel 8. Interaksi Antara Gaya Kognitif dan Pendekatan Problem Possing

Tests of Between-Subjects Effects

Dependent Variable: Hasil Belajar

\begin{tabular}{|l|r|r|r|r|r|r|}
\hline Source & $\begin{array}{c}\text { Type III Sum } \\
\text { of Squares }\end{array}$ & df & Mean Square & \multicolumn{1}{c|}{ F } & \multicolumn{1}{c|}{ Sig. } & $\begin{array}{c}\text { Partial Eta } \\
\text { Squared }\end{array}$ \\
\hline Corrected Model & $5309,411^{\mathrm{a}}$ & 3 & 1769,804 & 17,846 &, 000 &, 448 \\
Intercept & 315806,026 & 1 & 315806,026 & 3184,486 &, 000 &, 980 \\
Kelas & 2768,550 & 1 & 2768,550 & 27,917 &, 000 &, 297 \\
Gaya_Kognitif & 1756,261 & 1 & 1756,261 & 17,710 &, 000 &, 212 \\
Kelas * Gaya_Kognitif & 143,973 & 1 & 143,973 & 1,452 &, 233 &, 022 \\
Error & 6545,232 & 66 & 99,170 & & & \\
Total & 336215,000 & 70 & & & & \\
Corrected Total & 11854,643 & 69 & & & & \\
\hline
\end{tabular}

a. $\mathrm{R}$ Squared $=, 448$ (Adjusted R Squared $=, 423$ )

Dari hasil out put diatas, terlihat pada baris interaksi antara gaya kognitif dengan pendekatan pemebelajaran, diperoleh nilai $\mathrm{F}=1,452$ dan nilai $p$-value $=0,233$. Karena nilai $p$-value lebih besar dari $\alpha=5 \%$ $(0,233>$ dari 0,05$)$ maka $\mathrm{H}_{0}$ diterima dan $\mathrm{H}_{1}$ ditolak, sehingga dapat disimpulkan bahwa tidak ada interaksi antara gaya kognitif dengan dan pendekatan pembelajaran terhadap prestasi belajar siswa.

\section{Pembahasan Hasil Penelitian}

Prestasi belajar siswa yang diajar dengan menggunakan pendekatan problem posing lebih baik dari pada siswa yang diajar dengan menggunakan pendekatan konvensional yang diketahui dari pengukuran tes prestasi belajar setelah melalui kegiatan pembelajaran. Hal ini dapat dilihat berdasarkan pengamatan peneliti pada saat penelitian, siswa yang diajar dengan pendekatan problem posing menjadi lebih tertarik mengikuti proses belajar mengajar setelah diberikan masalah-masalah atau soal-soal yang sudah ada untuk menyusun soal baru (problem posing). Siswa lebih aktif mengkonstruksi soal, siswa bebas mengajukan pertanyaan-pertanyaan atau soal-soal yang berkaitan dengan materi yang dipelajari dan juga mempersiapkan jawaban dari soal yang disusunnya secara kelompok. Mereka berusaha mencari solusi dari setiap masalah melalui interaksi baik siswa dengan siswa maupun siswa dengan guru sehingga peranan guru tidak terlalu dominan. Guru berperan sebagai fasilitator dan motivator dalam proses belajar mengajar. Dengan 
demikian, pengetahuan yang dibangun jauh lebih bermakna jika dibandingkan dengan pembelajaran dengan pendekatan konvensional.

Hasil analisis juga menunjukkan bahwa prestasi belajar matematika siswa yang diajar dengan pendekatan problem posing berbeda secara signifikan dengan siswa yang diajar dengan menggunakan pendekatan konvensional dengan nilai $t=5.282$ dan nilai $p$-value $=0.000$, dengan mengambil nilai $\alpha=0,05$ maka nilai $p$-value $<\alpha=0,05$ sehingga $\mathrm{H} 0$ ditolak dan $\mathrm{H} 1$ diterima. Hal ini berarti bahwa pendekatan problem posing memberikan hasil yang signifikan terhadap prestasi belajar matematika. Problem posing adalah suatu bentuk pendekatan dalam pembelajaran matematika yang menekankan pada perumusan soal, yang dapat mengembangkan kemampuan berpikir matematis atau menggunakan pola pikir matematis. Bagi siswa, pembelajaran dengan pendekatan problem posing merupakan keterampilan mental, siswa menghadapi suatu kondisi dimana siswa diberikan suatu permasalahan dan siswa memecahkan masalah tersebut. Dengan menerapkan pendekatan problem posing keterlibatan siswa untuk turut belajar merupakan salah satu indikator keefektifan pembelajaran. Siswa tidak hanya menerima materi dari guru, melainkan siswa juga berusaha menggali dan mengembangkan sendiri. Prestasi belajar tidak hanya menghasilkan peningkatan pengetahuan tetapi juga meningkatkan keterampilan berpikir. Oleh karena itu penerapan pembelajaran dengan pendekatan problem posing dapat melatih siswa belajar kreatif, disiplin, dan meningkatkan keterampilan berpikir siswa.

Hasil penelitian menunjukkan bahwa siswa yang memiliki gaya kognitif Field Independent lebih baik prestasi belajarnya dari pada siswa yang bergaya kognitif field dependent yang diukur melalui tes prestasi belajar. Hal ini terjadi karena siswa yang bergaya kognitif field independent dalam proses pembelajaran lebih menyukai bidang-bidang yang membutuhkan keterampilan-keterampilan analitis seperti matematika dibandingkan dengan siswa field dependent yang lebih cendrung memilih bidang-bidang yang melibatkan hubungan-hubungan interpersonal seperti bidang ilmu sosial, ilmu sastra atau ilmu perdagangan. Siswa field independent lebih percaya diri dan tidak mudah dipengaruhi oleh lingkungan sehingga apa yang diyakini benar, maka 
konsisten dalam pilihannya. Siswa yang bergaya kognitif field dependent sering mengalami kesulitan belajar dalam menganalisis masalah.

Khusus kepada siswa yang bergaya kognitif field independent diperoleh data bahwa prestasi belajar yang diajar dengan menggunakan pendekatan problem posing lebih baik dari pada prestasi belajar yang diajar dengan menggunakan pendekatan konvensional. Hal ini sangat wajar, karena siswa yang bergaya kognitif field independent memiliki kemampuan analitis yang baik dan cendrung lebih reflektif terhadap kemungkinan-kemungkinan klasifikasi pilihan. Mereka lebih tenang dan tidak bingung dalam persoalan berpikir induktif. Seorang field independent lebih senang mengamati pemrosesan informasinya sendiri sebagaimana pendekatan problem posing yang memberikan kesempatan kepada siswa untuk mengajukan pertanyaan atau soal-soal yang terkait dengan materi pelajaran jika dibandingkan dengan pembelajaran dengan pendekatan konvensional.

Uraian di atas menunjukkan bahwa individu yang diajar dengan pendekatan problem possing hasil belajar yang diperoleh lebih baik dari hasil belajar siswa dengan pendekatan konvensional. Dipertegas oleh penelitian-penelitian yang dilakukan oleh Syam (2008), Zulkifli (2003) dan pemaparan hasil penelitian oleh Siswono (1999) menyebutkan bahwa pendekatan problem possing jika diaplikasikan dalam proses pembelajaran secara periodik akan meningkatkan hasil belajar dan mendapat respon positif dari siswa dan siswa lebih mudah mengingat materi pelajaran, memahamai suatu konsep, mendorong siswa lebih banyak membaca materi dan kemampuan pemecahan masalah yang baik. Dalam penelitian ini juga menyimpulkan bahwa siswa yang memiliki gaya kognitif field independent lebih unggul dari pada gaya kognitif field dependent dalam perolehan prestasi belajar. Sesuai dengan yang dijelaskan oleh Witkin (1977) menyatakan bahwa orang yang memiliki gaya kognitif field independent lebih bersifat analitis, mereka dapat memilih stimulus berdasarkan situasi, sehingga persepsinya hanya sebagian kecil terpengaruh ketika ada perubahan situasi. Orang yang memiliki gaya kognitif field dependent mengalami kesulitan dalam membedakan stimulus melalui situasi yang dimiliki sehingga persepsinya mudah dipengaruhi oleh manipulasi dari situasi sekelilingnya. 
Hasil analisis juga menunjukkan bahwa nilai $\mathrm{t}=3.051$ dan nilai $\mathrm{p}$ value $=0.005$, dengan mengambil nilai $\alpha=0,05$, maka nilai $p$-value $<\alpha=$ 0,05 sehingga $H_{0}$ ditolak dan $H_{1}$ diterima, yang menyatakan ada perbedaan prestasi belajar matematika siswa antara siswa yang bergaya kognitif FD yang diajar dengan pendekatan problem posing dari prestasi belajar matematika siswa yang diajar dengan pendekatan konvensional.

Hasil analisis menunjukkan bahwa interaksi antara pendekatan problem posing dengan gaya kognitif tidak mempengaruhi prestasi belajar matematika siswa. Dengan demikian, ini berarti tingkat gaya kognitif dan pendekatan pembelajaran secara bersama-sama tidak memberikan perbedaan hasil yang signifikan terhadap prestasi belajar matematika siswa. Dengan kata lain rata-rata prestasi belajar siswa yang diajar dengan pendekatan problem posing lebih tinggi dari siswa yang diajar dengan pendekatan konvensional, baik untuk gaya kognitif field independent dan field dependent. Hal ini dapat terjadi karena dalam pembelajaran dengan menggunakan pendekatan problem posing siswa dapat melatih siswa belajar kreatif, disiplin, dan meningkatkan keterampilan berpikir siswa. Hasil analisis data diperoleh juga koefisien determinasi, koefisien determinasi (R2) adalah 0.484 . Hal ini bisa diartikan gaya kognitif dan pendekatan mengajar memberikan kontribusi sebesar $48,4 \%$ pada prestasi belajar matematika siswa dan $51,6 \%$ dipengaruhi oleh variabelvariabel lain (selain gaya kognitif dan pendekatan mengajar).

\section{Kesimpulan dan Saran}

Dari hasil penelitian yang telah dilakukan, maka peneliti dapat menarik beberapa kesimpulan sebagai berikut:

1. Ada perbedaan prestasi belajar matematika siswa antara siswa yang diajar dengan pendekatan problem posing dan siswa yang diajar dengan pendekatan konvensional.

2. Prestasi belajar matematika siswa antara siswa yang bergaya kognitif field independent lebih baik dari prestasi belajar siswa yang bergaya kognitif field dependent.

3. Prestasi belajar matematika siswa antara siswa yang bergaya kognitif FI yang diajar dengan pendekatan problem posing lebih baik dari prestasi belajar siswa yang diajar dengan pendekatan konvensional. 
4. Ada perbedaan prestasi belajar matematika siswa yang mempunyai gaya kognitif field dependent yang diajar dengan pendekatan problem posing dari prestasi belajar matematika siswa yang diajar dengan pendekatan konvensional.

5. Tidak ada interaksi antara pendekatan problem posing dan gaya kognitif terhadap prestasi belajar matematika siswa.

Berdasarkan kesimpulan di atas, maka peneliti menyarankan beberapa hal yang perlu diperhatikan:

1. Banyaknya jenis pendekatan yang ada sekarang, guru diharapkan mampu menerapkan berbagai pendekatan dalam pembelajaran matematika yang mampu mengakomodir gaya kognitif yang dimiliki siswa sehingga terjadi peningkatan prestasi belajar matematika.

2. Pendekatan problem possing dalam pembelajaran terbilang masih baru berada di Indonesia, yaitu sekitar tahun 2000. Oleh karena itu diharapkan implementasi dan pengembangan dari pendekatan pembelajaran ini, karena dengan pendekatan problem posing siswa dilatih untuk memperkuat dan memperkaya konsep-konsep dasar matematika. Selain itu, pembelajaran problem posing merupakan keterampilan mental, siswa menghadapi suatu kondisi dimana diberikan suatu permasalahan dan siswa memecahkan masalah tersebut.

\section{Daftar Pustaka}

Arikunto, S. (1990). Manajemen pengajaran secara manusiawi. Jakarta: Rineka Cipta.

Departemen Pendidikan dan Kebudayaan. (1999). Bahan pelatihan penelitian. Direktorat Jendral Pendidikan Dasar Dan Menengah Umum. Jakarta

English, Lyn D. (1997). "Promoting a Problem Posing Classroom". Teaching Children Mathematics. 4 (3), 172-179

Hamzah. (2002). Pengembangan Model Pembelajaran Matematika di SLTP melalui pendekatan mathematical problem posing. Majalah IImiah Himpunan Matematika Indonesia (MIHMI). 8/3. 29-38.

Moses, B., Bjork, E., \& Goldenberg, E. P. (1993). “Beyond Problem Solving: Problem Posing". Stephen I. Brown dan Marion I. Walter (Ed). Problem Posing: Reflections and Applications. 178-188. New Jersey: Lawrence Erlbaum Associates, Publishers. 
National Council of Teachers of Mathematics. Commission on Teaching Standards for School Mathematics. (1991). Professional standards for teaching mathematics. Natl Council of Teachers of.

National Council of Teachers of Mathematics (Ed.). (2000). Principles and standards for school mathematics (Vol. 1). National Council of Teachers of.

Sembiring, R.K., Hadi, S., \& Dolk, M. (2008). Reforming mathematics learning in Indonesian classroom through RME. ZDM Mathematics Education, 40, 927-939.

Siswono, T. Y. E. (1999). Metode Pemberian Tugas Pengajuan Soal (Problem Posing) dalam Pembelajaran Matematika Pokok Bahasan Perbandingan di Mts Negeri Rungkut Surabaya. Tesis PPs Tidak diterbitkan Unesa.

Slameto, 2003. Belajar dan Faktor-faktor yang Mempengaruhinya. Jakarta: Rineka Cipta.

Soedjadi, R. (1999). Kiat pendidikan matematika di Indonesia. Jakarta: Depdikbud.

Soedjadi, (2001). Pembelajaran matematika realistik pengenalan awal dan praktis. Makalah Disampaikan Kepada Guru SD/MI Terpilih.

Soedjadi. (1991). Miskonsepsi matematika dalam pembelajaran matematika.

Makalah Disampaikan pada Seminar Pendidikan Sains dan Matematika. IKIP Surabaya.

Sugiyono. (2008). Metode penelitian pendidikan (Pendekatan kuantitatif, kualitatif, dan R\&D). Bandung: Alfabeta.

Suryanto. (1998). Pembentukan Soal Dalam Pembelajaran Matematika. Makalah Seminar Nasional, PPs IKIP Malang.

Syam, H. (2008). A problem possing approach that have cooperative instructional backround to increase mathematics instructional effectivennes. Tesis. UM. Malang

Upu, H. (2003). Problem posing dan problem solving dalam pembelajaran matematika. Bandung: Pustaka Ramadhan.

Wahyu, K. (2015). Changing mathematics classroom setting: Looking into students' responses and performance in learning. International Conference on Mathematics, Science and Education (pp. 113-121). Mataram: FKIP Universitas Mataram.

Wahyu, K., \& Mahfudy, S. (2016). Sejarah matematika: Alternatif strategi pembelajaran matematika. Beta Jurnal Tadris Matematika, 89-110.

Witkin, J. (1977). The Pseudo-Conceptual and The Pseudo_Analitycal arthought Processes in Mathematics Learning. Journal Educational Studies in Mathematics, 34, 97-129.

Zulkifli. (2003). Penerapan Pendekatan Problem Possing dalam Pembelajaran Pokok Bahasan Teorema Phytagoras di Kelas 2 SLTP 22 Surabaya. Tesis tidak diterbitkan. PPs Unesa 